\title{
A civilização como missão: agentes civilizadores de índios na Bahia colonial no contexto da politica pombalina
}

Fabricio Lyrio Santos[1]

\begin{abstract}
Resumo
O surgimento da palavra civilização e a definição de uma nova política indigenista no âmbito da legislação promulgada no período pombalino projetaram no cenário colonial a figura dos agentes leigos, ministros civis ou militares encarregados de modificar os costumes indígenas, ocupando o espaço deixado pelos missionários, principalmente após a expulsão dos jesuítas. Este artigo discute a atuação desses agentes e sua importância para a implantação da política pombalina na Bahia, na segunda metade do século XVIII, tendo em vista o crescente processo de afirmação e difusão dos ideais de "civilidade" e "civilização" dos índios.
\end{abstract}

Palavras-chave: civilização; índios; Bahia; século XVIII.

\section{Civilization as a mission: civilizing agents and indigenous people in Bahia during the Pombaline reform}

\section{Abstract}

The appearance of the word civilization within the context of a new indigenous policy by the Pombaline reform created in the colonial society the characters of layman agents, civil or military officers appointed to change the indigenous customs, so replacing the missionaries, especially after the expulsion of the Jesuits. This paper discuss the role of these agents and their relevance to the implementation of the Pombaline policy in Bahia in the second half of the 18th century, considering the Indian's growing process of affirmation and diffusion of the ideas of "civility" and "civilization".

Keywords: Civilization; Indigenous people; Bahia; 18th Century.

La civilización como misión: los agentes civilizadores de los indios en Bahía colonial, en el contexto de la política Pombalina

\section{Resumen}

El surgimiento de la palabra civilización y la definición de una nueva política indigenista bajo el gobierno del Marqués de Pombal han diseñado en el escenario colonial la figura de agentes laicos, ministros civiles o militares, a cargo de modificar las costumbres indígenas, ocupando el espacio dejado por los jesuitas, sobre todo después de su expulsión. El presente artículo analiza el papel de estos agentes y su importancia en la implementación de la política Pombalina en la Bahía de la segunda mitad del siglo XVIII, considerando el amplio proceso de afirmación y difusión de los ideales "cortesanos" y de "civilización".

Palabras clave: Civilización; Indios; Bahia; Siglo XVIII.

\section{La civilisation comme mission: agents civilisateurs d'indiens à Bahia à l'époque coloniale dans le contexte des réformes politiques de Pombal}

\section{Résumé}

L'usage du mot civilisation et la définition d'une nouvelle politique indienne dans le cadre de la législation promulguée à l'époque du gouvernement du Marquis de Pombal ont fait surgir des nouveaux acteurs sur la scène coloniale. En effet, les agents laïcs, ministres civils ou militaires, chargés du changement des mœurs des indiens, occupèrent la place des missionnaires, principalement après l'expulsion des jésuites. Cet article étudie laction de ces agents et le rôle qu'ils ont joué dans la mis-en-place de la politique du Marquis de Pombal à Bahia, pendant la deuxième moitié du XVIIIe siècle, considérant la montée du processus d'affirmation et de diffusion des idéaux de "civilité" et de "civilisation" des indiens.

Mots-clés : Civilisation; Indiens ; Bahia; XVIIIe siècle. 


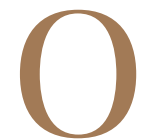

surgimento da palavra civilização representa um acontecimento singular na história política e cultural da Europa (Elias, 1994; Boer, 2007). No caso de Portugal, ela se insere no contexto do pensamento reformista ilustrado vigente no reinado de d. José (1750-1777), ganhando força a partir das mudanças introduzidas na legislação colonial por Sebastião José de Carvalho e Mello, futuro marquês de Pombal, e por seus principais colaboradores, entre os quais Francisco Xavier de Mendonça Furtado, governador e capitão-geral do estado do Grão-Pará e Maranhão (1750-1759), que elegeu os povos indígenas como alvo privilegiado de uma política que podemos definir como “civilizatória" (Almeida, 1997; Domingues, 2000; Falcon, 1993; Maxwell, 1996).

Tal política está definida em documentos programáticos, como o Diretório dos Índios, de 1757, e em textos normativos, como a lei de 6 de junho de 1755 e os alvarás com força de lei de 7 de junho de 1755 e 8 de maio de 1758. Embora apoiados em elementos existentes na prática colonial e catequética luso-brasileira desde o século XVI, tais textos trouxeram mudanças importantes, entre as quais a diminuição significativa do papel da Igreja, principalmente do clero regular, na política relativa aos povos indígenas, que se aprofunda com a expulsão dos jesuítas do Reino e domínios lusitanos após 1759. Os ministros civis encarregados de implementar essa política nos diferentes espaços coloniais serão aqui denominados "agentes civilizadores dos índios", pois tinham como principal missão, nos termos da referida legislação, "civilizá-los”, torná-los "civis", ou seja, promover sua "civilidade".

\section{Os ministros nomeados pelo Conselho Ultramarino}

$\mathrm{Na}$ Bahia, os principais agentes encarregados da implantação da política pombalina foram os ministros designados para transformar as aldeias indígenas em vilas ou lugares, de acordo com a lei de 6 de junho de 1755 e o alvará de 8 de maio de 1758 (Santos, 2012). Essa tarefa coube a autoridades coloniais que ocupavam posições estratégicas para a execução das diligências necessárias, as quais foram determinadas por um tribunal especial do Conselho Ultramarino instalado na cidade de Salvador, em setembro de 1758, composto pelos desembargadores Antônio de Azevedo Coutinho, Manoel Estevão de Almeida Vasconcelos Barberino e José Mascarenhas Pacheco Coelho de Mello, e presidido pelo vice-rei do estado do Brasil, d. Marcos de Noronha e Brito, sexto conde dos Arcos (Santos, 2012, p. 99-103).

Tendo em vista que as aldeias situavam-se a grandes distâncias em relação umas às outras e à cidade de Salvador, foi necessário dividir a execução das diligências entre vários ministros. Para chegar às que ficavam no sertão da capitania, por exemplo, era necessário vencer uma viagem que durava cerca de 15 dias, por terra, ou seguir de barco até a vila de Cachoeira, no recôncavo baiano, para depois percorrer uma distância de 40 léguas (cerca de 220 a $240 \mathrm{Km}$ ) até a aldeia de Natuba. De lá restavam ainda distâncias

${ }^{2}$ Deixamos esses termos entre aspas para evitar qualquer valoração, positiva ou negativa, a seu respeito. 
consideráveis até as aldeias próximas de Canabrava, Saco dos Morcegos e Geru, esta última localizada na capitania de Sergipe d'El Rei (ver a Figura 1). À época, avaliava-se em pelo menos um dia de viagem o tempo necessário para se percorrer uma distância de 10 léguas (cerca de $60 \mathrm{Km}$ ). Não por acaso, os ministros responsáveis pela criação das vilas foram escolhidos entre aqueles que conheciam as regiões onde se encontravam estas e as demais aldeias administradas pelos jesuítas.

Figura 1. Localização aproximada das aldeias jesuíticas do sertão da Bahia. Fonte: AHU/BA, avulsos, cx. 138, doc. 10.673.

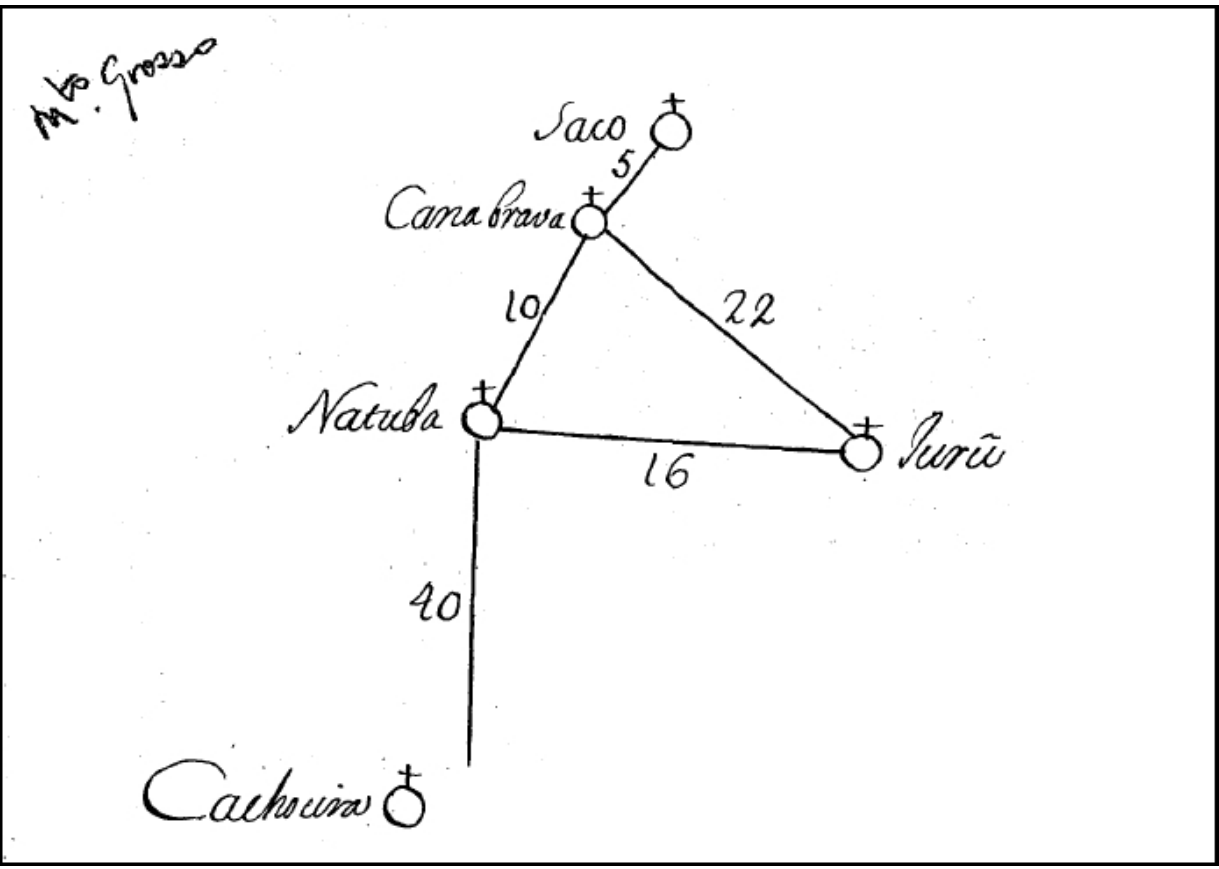

Tais ministros (ver quadro a seguir) foram instruídos a se deslocar até as aldeias e a intimar os religiosos a deixá-las tão logo chegassem os novos párocos nomeados pelo arcebispo, publicar perante os índios as leis anteriormente citadas, determinar a elevação da aldeia à condição de vila, erguer o pelourinho no meio da praça e supervisionar as eleições para vereadores e juiz ordinário, entre outras atribuições. Além disso, recolheriam informações importantes sobre as aldeias, seguindo um roteiro ou questionário elaborado pelo conselheiro José Mascarenhas Pacheco Pereira de Melo, principal encarregado de tais diligências. ${ }^{3}$ 
Distribuição dos ministros encarregados de criar as novas vilas

Fonte: Santos (2012, p. 124).

\begin{tabular}{lll}
\multicolumn{1}{c}{ Ministro } & \multicolumn{1}{c}{ Função } & \multicolumn{1}{c}{ Vilas } \\
\hline Luiz Freire de Veras & $\begin{array}{l}\text { Ouvidor e corregedor da } \\
\text { comarca da Bahia }\end{array}$ & $\begin{array}{l}\text { Olivença, Barcelos e } \\
\text { Santarém }\end{array}$ \\
\hline José Gomes Ribeiro & $\begin{array}{l}\text { Juiz de fora da vila da } \\
\text { Cachoeira }\end{array}$ & Soure \\
\hline $\begin{array}{l}\text { Miguel de Arez Lobo de } \\
\text { Carvalho }\end{array}$ & $\begin{array}{l}\text { Ouvidor e corregedor da } \\
\text { comarca de Sergipe d'El Rei }\end{array}$ & $\begin{array}{l}\text { Pombal, Mirandela e } \\
\text { Távora }\end{array}$ \\
\hline Antônio da Costa Souza & $\begin{array}{l}\text { Capitão-mor da capitania } \\
\text { de Porto Seguro }\end{array}$ & Trancoso e Vila Verde \\
Manoel da Cruz Freire & $\begin{array}{l}\text { Ouvidor da capitania de } \\
\text { Porto Seguro }\end{array}$ & Trancoso e Vila Verde \\
\hline $\begin{array}{l}\text { Francisco de Salles } \\
\text { Ribeiro }\end{array}$ & $\begin{array}{l}\text { Ouvidor e corregedor da } \\
\text { comarca da capitania do }\end{array}$ & Benevente e Almeida \\
\hline $\begin{array}{l}\text { João Ferreira de } \\
\text { Bitencourt e Sá }\end{array}$ & $\begin{array}{l}\text { Juiz de fora da cidade da } \\
\text { Bahia }\end{array}$ & Abrantes \\
\hline
\end{tabular}

O ministro cuja atuação mais se destaca na documentação é o juiz de fora da cidade da Bahia, João Ferreira de Bitencourt e Sá. Ele ficou responsável pela criação da vila de Abrantes, na antiga aldeia do Espírito Santo de Ipitanga, localizada no litoral a cerca de sete léguas (aproximadamente $40 \mathrm{Km}$ ) ao norte de Salvador. A aldeia havia sido fundada no segundo semestre de 1558 e fazia parte do primeiro grupo de aldeamentos organizados pelos jesuítas no século XVI (Leite, 1938-1950, t. II, p. 53). Sua localização favoreceu a realização das diligências e a antecipação dos problemas que seriam enfrentados nas demais (Brunet, 2008; Santos, 2002 e 2012).

Bittencourt e Sá encaminhou informações detalhadas acerca das dúvidas suscitadas pelas diligências necessárias para a criação da vila, as quais foram apreciadas pelos membros do tribunal especial do Conselho Ultramarino instalado em Salvador. Em sua primeira prestação de contas, datada de 11 de outubro de 1758, informou que no dia 8 do mesmo mês havia mandado erguer o pelourinho - ato oficial de criação da vila - após reunir os índios e outras pessoas ali presentes para ouvirem as deliberações régias relativas à liberdade dos índios e à transformação daquela aldeia em vila. Em seguida, foram eleitos um juiz ordinário, três vereadores, um procurador da câmara e um escrivão, que ficaria servindo também de tabelião de notas, escrivão do judicial e do juízo de órfãos. Todos foram providos, prestaram juramento e tomaram posse na câmara, instalada na antiga residência dos jesuítas, por decisão do ministro, por ser a única construção com capacidade para acomodar as audiências. ${ }^{4}$

Os índios com as mais altas patentes da aldeia (capitão-mor e sargentomor) foram, inicialmente, mantidos em seus postos. Pedro Reis, escolhido

${ }^{4}$ AHU/BA, avulsos, cx. 139, doc. 10.701 
para juiz ordinário, Antônio Borges, eleito para uma das vagas de vereador, e Jeronimo de Albuquerque, nomeado para o cargo de procurador, eram "filhos de Europeus e creados na Cidade", embora vivessem há muitos anos na aldeia com suas mulheres e filhos. O mesmo Pedro Reis, ou Pedro dos Reis, foi posteriormente nomeado capitão-mor das ordenanças da vila e permaneceu no cargo até seu falecimento, por volta de 1789, quando o governador, d. Fernando José de Portugal, proveu no mesmo posto o alferes Maurício da Silva Lima. ${ }^{5}$ Ele aparece na lista dos índios "que sabem ler suficientemente e escrever muito mal", elaborada pelo próprio Bittencourt e Sá, ao lado de Jeronimo Xavier, nomeado para escrivão da câmara, Francisco Xavier, nomeado para escrivão do alcaide, e Francisco Lopes, que ocupou uma das vagas de vereador. No total, apenas oito moradores da futura vila aparecem na lista, e um deles, Jeronimo Peres, nomeado para porteiro, sabia apenas ler. ${ }^{6}$

\section{Ministros foram instruídos a se deslocar até as aldeias e a intimar os religiosos a deixá-las tão logo chegassem os novos párocos nomeados pelo arcebispo}

A mistura com portugueses (tanto em termos políticos e de convivência quanto de casamento e miscigenação), o domínio do idioma português e da escrita e a ocupação dos postos de milícia eram vistos como fundamentais para o processo de "civilização". O próprio Bittencourt e Sá opina a esse respeito no relatório final que encaminhou ao tribunal do Conselheiro Ultramarino, no qual afirma:

Será tambem muito util que se misturem na governança, e em cada vereaçaõ ao menos dous Portuguezes, principalmente sendo cazado com Indias e estabelecidos com igualdade entre elles, para por este modo se civilizarem com mais facilidade, e se desterrar totalmente naõ só o nome de Indios, a cor, mas os preguiçozos, maos, e viciozos costumes desta nasçaõ, porque a exemplo dos Pays Europeos se poderaõ criar os filhos, com melhor ensino, fé, e educaçaõ, tanto nos preceitos da Religiaõ Catholica, em que saõ pouco credulos, como no trato civil, e diligencia de lavouras. ${ }^{7}$

Outro diligente ministro na implantação da política pombalina na Bahia foi o ouvidor e corregedor da referida comarca, Luiz Freire de Veras, que ficou responsável pela criação das novas vilas de Olivença, Barcelos e Santarém, em lugar das aldeias de Nossa Senhora da Escada, Maraú e Serinhaém, todas elas

${ }^{5}$ AHU/BA, Castro e Almeida (doravante C.A.), cx. 82, doc. 16.001.

${ }^{6}$ AHU/BA, avulsos, cx. 139, doc. 10.701. Essa documentação também pode ser encontrada em: Arquivo Público do Estado da Bahia (doravante Apeb), seção colonial e provincial, mç. 603.

${ }^{7}$ AHU/BA, avulsos, cx. 139, doc. 10.701. As citações de fontes manuscritas do período em estudo foram feitas respeitando-se a grafia original. 
localizadas na capitania e futura comarca de Ilhéus (Marcis, 2013, p. 207-215). Luiz Freire de Veras foi também designado para tomar posse daquela capitania para a Coroa a fim de que nela fosse criada uma ouvidoria (Adan, 2009, p. 60). Antes de seguir viagem, recebeu instruções específicas baseadas nas questões enfrentadas durante a criação da vila de Abrantes e lembrou aos conselheiros que era preciso levar consigo o material necessário para as diligências, a saber: sete varas pintadas para serem entregues aos novos oficiais, quatro livros para a câmara e três para o escrivão e uma cópia das ordenações do Reino. O ouvidor observou também que era importante definir quem ficaria responsável pelas despesas referentes às demarcações dos distritos das novas vilas. Seu requerimento obteve deliberação favorável, sendo-lhe determinado que as despesas ficassem por conta dos próprios ministros, os quais posteriormente seriam ressarcidos pela Fazenda Real. ${ }^{8}$

Além de criar as novas vilas para as quais fora designado, Luís Freire de Veras reuniu informações sobre elas e também sobre a aldeia de Nossa Senhora da Conceição dos Índios Grens, para a qual não se havia designado nenhum ministro. Esta deveria ser convertida em vila com o nome de Nova Almada, o que acabou por não se concretizar, permanecendo a povoação com status de aldeia (Marcis, 2013, p. 237).

O ouvidor da comarca de Sergipe d'El Rei, Miguel de Ares Lobo de Carvalho, ficou responsável pela criação das três vilas de Távora, Pombal e Mirandela, em lugar, respectivamente, das antigas aldeias de Geru, Canabrava e Saco dos Morcegos. As duas últimas ficavam fora de sua jurisdição, embora estivessem mais próximas da sede de sua comarca do que da cidade de Salvador, razão pela qual o vice-rei precisou muni-lo de poderes extraordinários para a execução das diligências. Posteriormente, em decorrência da condenação da família Távora pelo atentado fracassado contra a vida do rei d. José, em 3 de setembro de 1758, a vila nova de Távora teve o nome alterado para Tomar. ${ }^{9}$

Após o decreto de expulsão dos jesuítas, em 1759, Miguel de Ares Lobo de Carvalho atuou no sequestro dos bens e escravos das fazendas localizadas em sua comarca (Tejupeba e Jaboatão), bem como na prisão e no envio dos quatro padres ali residentes em custódia até a cidade de Salvador. Em seguida, foi o primeiro ouvidor nomeado para a recém-criada comarca de Ilhéus (Adan, 2009, p. 62). Em 1768, foi acusado pelo desembargador Rodrigo Coelho Machado Torres de ser um mau ministro, pesando contra si, entre outras questões, a fama de ter procedido mal no sequestro dos bens dos jesuítas. ${ }^{10}$

O juiz de fora da vila da Cachoeira, José Gomes Ribeiro, foi o responsável pela transformação da aldeia de Natuba em vila com o nome de Nova Soure. Ribeiro foi posteriormente nomeado ouvidor do crime. Em 1768,

\footnotetext{
${ }^{8}$ AHU/BA, avulsos, cx. 138, doc. 10.676. O autor foi identificado equivocadamente na descrição desse documento como "ouvidor da vila da Nova Abrantes", cargo que sequer existia.

${ }^{9}$ AHU/BA, C.A., cx. 40, doc. 7.557. Ver certidão anexa ao documento.

${ }^{10}$ AHU/BA, C.A., cx. 42, doc. 7.875.
} 
foi considerado pelo recém-chegado marquês do Lavradio como um bom ministro. ${ }^{11}$

O capitão-mor de Porto Seguro, Antônio da Costa Souza, e o ouvidor interino, Manoel da Cruz Freire, ficaram responsáveis pelas duas únicas aldeias administradas pelos jesuítas naquela capitania e futura comarca, São João e Espírito Santo, conhecida como Patatiba, tendo criado duas novas vilas, Trancoso e Verde (Cancela, 2012, p. 103-111).

O ouvidor e corregedor da comarca do Espírito Santo, Francisco de Sales Ribeiro, foi o responsável pelas aldeias localizadas naquela antiga capitania subordinada ao governador da Bahia, tendo concluído suas diligências apenas em abril de 1762, como informa em carta dirigida ao monarca. Nela constam os autos de criação das respectivas vilas de Almeida e Benevente. ${ }^{12}$

Como já foi referido, o método de criação das novas vilas foi definido a partir da experiência adquirida com a criação da nova vila de Abrantes. Mediante as informações do ministro responsável por aquela diligência, foram estabelecidas instruções específicas que previam a eleição de apenas dois vereadores nas aldeias onde houvesse poucos índios capazes para o exercício dos cargos públicos, permitia-se que os índios que não soubessem ler e escrever pudessem ser nomeados para os cargos de juízes e oficiais, que para o cargo de escrivão pudesse ser eleito um português, caso não houvesse na aldeia nenhum índio "inteligente em procesar, e bem morigerado, excluindo sempre o que for de genio trefego, e orgulhozo". ${ }^{3}$

A questão relativa à nomeação de escrivães portugueses revelou-se uma mudança fundamental em relação ao que estava anteriormente determinado na lei de 6 de junho de 1755. Em acréscimo, o referido escrivão poderia também servir, se necessário, de escrivão do alcaide e de mestre de ler e escrever para os meninos, ajustando-se um pagamento anual, o qual não poderia exceder 80 mil réis. Posteriormente, como será visto a seguir, após tomarem conhecimento do Diretório dos Índios e opinando acerca de sua aplicação nas povoações indígenas da jurisdição da Bahia, os conselheiros defenderiam que os mesmos escrivães assumissem também as funções que deveriam ficar a cargo dos diretores, tornando esse cargo o de maior importância e atribuições nas novas vilas indígenas.

\section{Os escrivães-diretores}

Concomitante às diligências executadas na Bahia, teve lugar em Lisboa a promulgação do Diretório dos Índios, documento que, entre outras medidas, criava o cargo de diretor das povoações e vilas indígenas. Este se constituía em autêntico “civilizador dos índios", já que esta consistia em sua principal obrigação, própria

\footnotetext{
"AHU/BA, C.A., cx. 42, doc. 7.873. Sobre as informações recolhidas por esse ministro durante as diligências de criação dessa vila, ver Santos (2012, p. 124-129).

${ }^{12}$ Arquivo Histórico Ultramarino. Conselho Ultramarino. Brasil, avulsos, cx. 18, doc. 1.565.

${ }^{13} \mathrm{AHU} / \mathrm{BA}$, avulsos, cx. 138, doc. 10.697. As instruções correspondem aos anexos n. 32,37 e 38.
} 
de seu ministério. A civilidade definia-se, primordialmente, pelo aprendizado e uso do idioma português, pelo aprendizado da doutrina cristã e dos ofícios "próprios de cada sexo" (ler, escrever e contar, para os meninos, ler, escrever, fiar, fazer renda e costurar, para as meninas), no tratamento diferenciado das pessoas "segundos suas graduações e cabedais", no abandono da embriaguez e na adoção dos usos e costumes portugueses (nomes próprios, vestimenta, moradia etc.). Além disso, deveriam demonstrar maior propensão para o trabalho e a produção de gêneros necessários para subsistirem e promoverem "a opulência, e a total felicidade do Estado.". ${ }^{4}$

No entanto, como foi visto anteriormente, os conselheiros ultramarinos responsáveis pela aplicação da lei de 6 de junho de 1755 e dos alvarás de 7 de junho de 1755 e de 8 de maio de 1758 já haviam partido de Lisboa quando o Diretório foi aprovado, em 17 de agosto de 1758, e haviam tomado diversas deliberações importantes quando dele tomaram conhecimento, no ano seguinte, com a ordem de que fosse observado "nas Aldeas da jurisdiçaõ desse Estado, em todas aquellas partes, que lhes possaõ ser applicaveis". ${ }^{15}$

Reunidos com o vice-rei, os conselheiros se debruçaram sobre os 95 parágrafos do Diretório visando a determinar o que seria ou não pertinente à jurisdição daquele governo, produzindo um longo parecer (Cancela, 2012, p. 122-141; Marcis, 2013, p. 131-149; Santos, 2012, p. 205-207). Foi descartada, de início, a proposição básica do documento, estabelecida no primeiro parágrafo, a saber: a nomeação de diretores para as povoações indígenas. Os membros do tribunal entenderam que esta se fazia impraticável "por falta de pessoas, em que concorrão as qualidades que essencialmente se requerem ou lhes prescreve o mesmo §". Em contrapartida, sugeriram que os escrivães nomeados para as câmaras das novas vilas ocupassem interinamente essa função, ou seja, "a direcção das povoaçoens em que residem". Tais "escrivães-diretores" seriam encarregados de ensinar os meninos a ler e a escrever e zelar pela observância dos parágrafos do Diretório considerados válidos para a administração das povoações indígenas daquele governo, entre os quais aqueles referentes à promoção da civilidade dos índios ( $\$ \$ 5-15)$. Esses e outros excertos do Diretório deveriam ser copiados e enviados aos escrivães para que os observassem e fizessem observar. ${ }^{16}$

Esse parecer foi duramente reprovado após o retorno do conde dos Arcos a Portugal por uma carta régia cuja minuta está datada de 20 de abril de 1761, na qual o rei mandava estranhar o procedimento adotado pelo vice-rei e o acusava de tentar invalidar o Diretório, ordenando aos governadores interinos da Bahia que lhe dessem a devida execução, não obstante os pretextos apresentados no documento. ${ }^{17}$

\footnotetext{
${ }^{14}$ Directorio, que se deve observar nas Povoaçoens dos Indios do Pará, e Maranhaõ, em quanto Sua Magestade naõ mandar o contrario. Lisboa, Na Officina de Miguel Rodrigues, MDCCLVIII, §§ 1-15; ibid., § 95. ${ }^{15}$ Apeb, ordens régias, liv. 61, doc. 98. Ver também AHU/BA, avulsos, cx. 139, doc. 10.706. ${ }^{16}$ AHU/BA, C.A., doc. 4.255-4.256. Transcrito em: Anais da Biblioteca Nacional do Rio de Janeiro (doravante ABNRJ), XXXI, p. 334-342. Também presente em: Apeb, Colonial e Provincial, mç. $201-75$.

${ }^{17}$ Biblioteca Nacional do Rio de Janeiro (doravante BNRJ). Setor de Manuscritos, cota: II, 30, 32, 30, doc. 1.
} 
Nota-se que os membros do Conselho Ultramarino não discordaram da indicação de diretores para as vilas, apenas entenderam que esta seria impraticável pela falta de pessoas capacitadas ou interessadas em ocupar esse cargo. Desse modo, a aplicação do Diretório dos Índios na jurisdição da Bahia ficou prejudicada. Os escrivães das câmaras foram obrigados a acumular a função de diretores, além das que já exerciam em decorrência da ausência de índios versados nas práticas administrativas lusitanas. Por outro lado, esse acúmulo de atribuições limitou as possiblidades de ascensão dos próprios índios, impossibilitados de exercer funções cruciais para o funcionamento de suas povoações.

De acordo com relatos do final do século XVIII, boa parte das povoações indígenas da Bahia era regida por "escrivães-diretores" nos termos propostos pelo parecer do tribunal do Conselho Ultramarino. O militar Domingos Álvares Branco Muniz Barreto, por exemplo, a respeito de quem falaremos a seguir, relatou a existência desses funcionários nas vilas de Santarém e Abrantes, que visitou entre 1791 e 1792. Nas povoações que não haviam se transformado em vilas, a situação estava ainda mais longe do proposto no Diretório. Na aldeia de São Fidelis, havia um "administrador" ou "administrador regente" que passava a maior parte do tempo na povoação de Una, sem residir na aldeia. Na de Massarandupió, o religioso carmelita ali residente exercia as funções de diretor, pároco e missionário, "ainda que contra o disposto no Directorio dos Indios e reprovado por direito canonico, que impede semelhante jurisdicção aos mendicantes". Na aldeia de Nossa Senhora dos Prazeres do Jequiriçá, por outro lado, não havia nem diretor nem pároco. ${ }^{18}$

Em um inquérito realizado no início do século XIX acerca da civilização dos índios das povoações da jurisdição da Bahia, revela-se uma situação semelhante à encontrada por Domingos Barreto. O ouvidor da comarca de Sergipe informou que a vila de Tomar tinha apenas um escrivão, que servia de diretor e professor de primeiras letras, além de um vigário secular. $\mathrm{O}$ governo da câmara era alternado entre índios e portugueses. As missões da Pacatuba, São Pedro (Porto da Folha) e Japaratuba eram "dirigidas" por seus missionários, os religiosos capuchinhos e carmelitas calçados. Na última havia também um "director portuguez", ou seja, supostamente um leigo. ${ }^{19}$

O ouvidor da comarca de Ilhéus informou que nas três vilas indígenas de Olivença, Barcelos e Santarém e nas duas aldeias de Almada e São Fidelis os índios eram governados por seus vereadores e juízes. Os escrivães nomeados para essas povoações acumulavam as funções de diretores e mestres de ler e escrever, embora não cumprissem devidamente essa última obrigação, desculpando-se pela ausência dos meninos à escola. ${ }^{20}$

${ }^{18}$ AHU/BA, C.A., cX. 81, doc. 15.794-15.799. Publicado parcialmente em: ABNRJ, XXXIV, p. 327-331.

${ }^{19}$ AHU/BA, C.A., CX. 133, doc. 26.328.

20 AHU/BA, C.A., CX. 133, doc. 26.329. A povoação de Almada, correspondente à antiga aldeia de Nossa Senhora da Conceição dos Indios Grens, deveria aparecer como vila, conforme determinação do Conselho Ultramarino. Entretanto, como já foi referido, a vila não foi estabelecida, sendo a aldeia convertida apenas em freguesia (Marcis, 2013, p. 22 e 237). 
Na comarca de Porto Seguro, segundo a informação dos moradores da vila do Prado dirigida ao ouvidor interino Francisco Dantas Barbosa, em 1803, havia também "escrivães-diretores" que ensinavam os índios a ler e a escrever, mas as escolas eram igualmente pouco frequentadas. ${ }^{21}$

Na comarca da Jacobina, os índios das povoações do Saí e do Bom Jesus eram "regidos" ou "governados" pelos missionários franciscanos, residentes em Salvador, segundo relatou, de modo sucinto, seu ouvidor, sugerindo a inexistência de diretores ou mesmo de escrivães-diretores. ${ }^{22}$

\section{A mistura com portugueses, o domínio do idioma português e da escrita e a ocupação dos postos de milícia eram vistos como fundamentais para $\mathrm{o}$ processo de "civilização"}

Na comarca da Bahia, portugueses e índios revezavam-se na governança das vilas. O ouvidor Luiz Thomaz Navarro de Campos compõe seu relato a partir das informações colhidas dos "administradores das Aldêas". Em determinado momento, ele próprio diferencia os termos "administrador", que usa para se referir à aldeia (missão) de Massarandupió, e "diretor", que usa para se referir à vila de Abrantes. Também cita em sua comarca a aldeia de Santo Antônio e as vilas de Nossa Senhora de Nazaré da Pedra Branca e Soure, mas não faz referência à presença ou não de diretores nessas povoações. ${ }^{23}$

Percebe-se que poucos ministros exerciam, efetivamente, o ofício de diretores, sendo mais comum o acúmulo dessa função com a de escrivão. Além disso, algumas povoações continuavam sendo regidas por religiosos, mantendo o status de aldeias. Nota-se o papel quase nulo dos diretores ou escrivães-diretores em relação à situação vivenciada nas vilas ou povoações indígenas, os quais parecem pouco atuantes em seu ofício, deixando aos ouvidores das respectivas comarcas a tarefa de prestar contas ao monarca acerca da maior ou menor "civilização" dos povos indígenas.

\section{Os ouvidores das novas comarcas}

A criação das novas comarcas de Ilhéus e Porto Seguro a partir da incorporação daquelas antigas capitanias à Coroa coincide com o período posterior à legislação pombalina e à expulsão dos jesuítas, estando relacionada com o processo mais amplo de reestruturação política, administrativa e econômica que caracteriza aquele período (Adan, 2009; Cancela, 2012; Marcis, 2013). Seus

\footnotetext{
${ }^{21}$ AHU/BA, C.A., cX. 133, doc. 26.332. Publicado em: ABNRJ, XXXVII, p. 178-179. Acerca da atuação dos "escrivãesdiretores" na ouvidoria de Porto Seguro, ver Cancela (2012, p. 212-218).

${ }^{22}$ AHU/BA, C.A., CX. 133, doc. 26327.

${ }^{23}$ AHU/BA, C.A., CX. 133, doc. 26.331.
} 
primeiros ouvidores podem ser igualmente identificados como "civilizadores de índios", visto que as vilas recém-criadas e as populações indígenas aldeadas ou livres ocuparam lugar primordial na política de fortalecimento da colonização naquelas regiões.

Essa questão revela-se extremamente relevante na comarca de Porto Seguro, onde o primeiro ouvidor, Thomé Couceiro de Abreu, tomou posse em dezembro de 1763, levando consigo um regimento que postulava, entre suas principais atribuições, a civilização dos índios e o desenvolvimento econômico da região. Os índios deveriam ser encarados como prioridade, sendo uma de suas principais obrigações a aplicação do Diretório, especialmente os $\$ \S 1^{\circ}$ a 15 (que diziam respeito à promoção de sua civilidade) e 16 a 24 (que se referiam ao incentivo à agricultura e ao comércio). Na ocasião, o próprio Francisco Xavier de Mendonça Furtado, ex-governador do estado do Grão-Pará e Maranhão e autor do Diretório dos Índios, de 1757, ocupava a Secretaria de Estados dos Negócios Ultramarinos. ${ }^{24}$

Para Francisco Cancela, o interesse do Estado português em promover "a reformulação do estatuto jurídico e social dos povos indígenas" em Porto Seguro tinha por objetivo "redimensionar a colonização daquela região, transformando-a em um polo produtor de víveres para a sustentação das cidades de Salvador e Rio de Janeiro". Desse modo, "os índios de Porto Seguro foram concebidos como agentes potenciais para a colonização da antiga donataria" (Cancela, 2012, p. 123).

Couceiro de Abreu deu notícias de sua comarca em janeiro de 1764, informando que havia chegado à vila de Porto Seguro no dia 7 de dezembro do ano anterior. De acordo com seu relato, vários índios das duas aldeias que haviam pertencido aos jesuítas estavam ausentes, pois os ministros responsáveis pela criação das vilas tinham-nos deixado "na mesma brutalidade, em que antes viviam", ou seja, continuavam morando em casas que abrigavam vários núcleos familiares, sem terras delimitadas para a criação de gado e para o rendimento da câmara. Não havia diretor, mas, nos termos do parecer emitido pelos conselheiros ultramarinos quanto à aplicação do Diretório, visto anteriormente, apenas um escrivão, "com obrigação de lhes ensinar seus filhos a ler".25

Escreveu novamente para o Reino seis meses depois, ponderando que o trabalho mais conveniente para se empregar os índios era o corte de madeiras, abundantes na região, o qual era realizado por eles desde o tempo dos jesuítas. Quanto às novas vilas de Trancoso e Verde, havia conseguido separar as famílias e aumentar a frequência dos meninos à escola, pois não costumavam frequentá-la antes de sua chegada. De acordo com o ouvidor, os índios consumiam

\footnotetext{
24 "Provisão de Sua Majestade concedida ao Bacharel Thomé Couceiro de Abreu no lugar de ouvidor da capitania de Porto Seguro", 10 de maio de 1763. Publicado em: Anais do Arquivo Público do Estado da Bahia, v. 1, 1917, p. 129-130. Ver também: "Instrucções dadas pelo Governo Portuguez a Thomé Couceiro de Abreu quando mandou este magistrado crear a Ouvidoria de Porto Seguro". Nossa Senhora da Ajuda, 30 de abril de 1763. Publicado em: Anais do Arquivo Público do Estado da Bahia, v. 1, 1917, p. 1-6. Sobre a nomeação de Mendonça Furtado para a secretaria de Estado, ver Monteiro (2006, p. 147-148).

${ }^{25}$ AHU/BA, C.A., doc. 6.429. Publicado em: ABNRJ, XXXII, p. 37-38. Também presente em: Revista do Instituto Geográfico e Histórico da Bahia, n. 83, p. 185-195.
} 
tudo o que ganhavam em aguardente. Para contornar essa situação, resolveu estabelecer um sistema no qual os moradores recrutavam a mão de obra indígena por seu intermédio, e a remuneração era feita em ferramentas e utensílios, como forma de forçá-los a trabalhar e de evitar que comprassem bebidas com seus salários. Couceiro de Abreu agiu também no sentido de criar novas vilas, buscando promover o povoamento da comarca. ${ }^{26}$

\section{Os escrivães das câmaras foram obrigados a acumular a função de diretores, além das que já exerciam em decorrência da ausência de índios versados nas práticas administrativas lusitanas}

Após seu falecimento, tomou posse daquela comarca o bacharel José Xavier Machado Monteiro. ${ }^{27}$ Em 1768, quando o marquês do Lavradio estava dando início a seu mandato como governador da Bahia, foi-lhe informado pelo desembargador Rodrigo Coelho Machado Torres que José Xavier Monteiro estava no princípio de sua ocupação no lugar de ouvidor e que era muito bom ministro. ${ }^{28}$ De fato, o novo ouvidor dedicou-se com afinco ao ofício de "civilizador dos índios" de sua comarca. Durante o período em que exerceu o cargo, redigiu diversas cartas e relatórios a respeito de suas atividades e das medidas que tomou a esse respeito, visando ao desenvolvimento da região (Cancela, 2012; Santos, 2012, p. 213-217).

Uma de suas principais contribuições no papel que lhe foi designado de "agente civilizador dos índios" foi a elaboração de instruções específicas para os diretores das povoações indígenas, visando "complementar e adaptar" o Diretório, tendo em vista as condições específicas encontradas em sua comarca (Cancela, 2012, p. 145-157).

De início, suas primeiras impressões a respeito dos índios foram extremamente negativas. Ele os considerou "os mais torpes, ociosos e viciosos do Brasil”. Aos poucos, enaltecendo sua própria atuação, José Monteiro afirmava ter conseguido diminuir o número dos "ébrios e vadios", fazendo com que se dedicassem à lavoura, criassem gado, andassem vestidos, deixassem de usar as línguas nativas, frequentassem a escola e aprendessem ofícios. Monteiro também se dedicou à fundação de novas vilas, habitadas tanto por índios quanto por portugueses, trabalhou para a reconstrução das igrejas e edifícios antes pertencentes aos jesuítas, desenhou plantas das vilas e estabeleceu

\footnotetext{
${ }^{26}$ AHU/BA, C.A., doc. 6.508. Publicado em: ABNRJ, XXXII, p. 50-53. Também presente em: Revista do Instituto Geográfico e Histórico da Bahia, n. 83, p. 195-217.

${ }^{27}$ Monteiro afirma que seu antecessor havia permanecido no cargo durante 16 meses, o que significa que ele teria falecido em abril de 1765. Cf. AHU/BA, C.A., doc. 8.446. Segundo Vilhena, José Xavier Machado tomou posse em 1766, permanecendo no cargo até por volta de 1780. Engana-se, entretanto, o cronista, ao afirmar que ele teria sido o primeiro ouvidor da comarca. Ver Vilhena (1969, v. II, p. 323).

${ }^{28}$ AHU/BA, C.A., cx. 42, doc. 7.875.
} 
regulamentos para os moradores. Além disso, orgulhava-se de não ter em sua comarca nenhum pleito de importância ou crime grave no tocante aos próprios índios e aos demais moradores. ${ }^{29}$

Suas principais medidas "civilizacionais" foram as seguintes: separação entre adultos e crianças, de modo a que estas não se "contaminassem" com os "vícios" impossíveis de ser tirados dos mais velhos; obrigação do trabalho cotidiano e da prestação de serviços aos colonos; remuneração em roupas e ferramentas, a fim de que não comprassem aguardente ou coisas inúteis para o trabalho; frequência obrigatória dos meninos à escola $\mathrm{e}$ entrega das meninas às mulheres dos colonos para que aprendessem ofícios e andassem bem vestidas; vigilância constante quanto ao uso das línguas e costumes nativos. ${ }^{30}$

Apesar de diligente e incansável "no desvelo de civilizar os índios", Monteiro mostrava-se insatisfeito com o cargo. Deveria tê-lo exercido por apenas três anos, desde sua nomeação, mas acabaria permanecendo naquela comarca durante mais de uma década. Em 1777, decerto em função da morte do monarca que o havia nomeado e da ascensão de d. Maria I ao trono português, reportou-se diretamente à rainha, encaminhando-lhe uma carta à qual anexara um extenso relatório do que havia realizado desde o dia 3 de maio de 1767 até o final de julho de 1777. Reputava os índios mais civilizados do que antes, estando sempre "ocupados ou no próprio serviço das suas roças, que duas vezes cada ano manda examinar, ou no alheio, com que os tem rebatido na vadiação e feito aumentar em benefício público os frutos da terra e do mar". Andavam todos vestidos, "quando menos de camisa e calção". Os filhos e as filhas, apartados da companhia dos pais, esqueciam aos poucos "o uso da língua bárbara". Viviam melhor que estes e mais bem vestidos, atraindo os brancos para o casamento. Monteiro pedia que por esses serviços não recebesse outra mercê que não fosse o de ser substituído e poder regressar ao Reino,

[...] por me ver decrépito com 63 para 64 anos de idade, atacado de achaques, que consigo traz a velhice, maiormente adquiridos na desordenada fadiga, com que todos os anos e em qualquer rigor do tempo, em país tão adusto, por praias quase de 100 léguas de ida e outras tantas de volta, me arrebatava no zelo de desempenhar as obrigações da minha conduta. ${ }^{31}$

A estratégia adotada por Monteiro de tirar as crianças da influência dos pais remete aos métodos usados pelos missionários, principalmente jesuítas, desde o século XVI, de introduzir o cristianismo nos índios desde a mais tenra idade (Chambouleyron, 2004). Isso sugere que a catequese empreendida pelos religiosos até o período pombalino diferia menos do que se possa imaginar

${ }^{29}$ AHU/BA, C.A., doc. 7.972. Publicado em: ABNRJ, XXXII, p. 207-208. Os desenhos e mapas estão presentes na seção de cartografia do Arquivo Histórico Ultramarino.

30 Monteiro explicita seus métodos e os resultados supostamente alcançados na região em diversas cartas e ofícios endereçados ao Reino. A título de exemplo, ver AHU/BA, avulsos, cx. 164, doc. 12.457.

${ }^{31}$ AHU/BA, C.A., cx. 51, doc. 9.492. De acordo com Vilhena, Monteiro foi substituído apenas em 1781, quando tomou posse Bento José de Campos e Souza. Ver Vilhena (1969, v. 2, p. 323). 
do processo supostamente "civilizatório". A retórica civilizacional, no entanto, contrapunha fortemente os dois modelos, imputando ao primeiro tudo que reprovava nos índios, da inconstância religiosa à persistência gentílica.

\section{O militar ilustrado Domingos Barreto}

Apesar da atuação dos ouvidores e das demais autoridades mencionadas anteriormente, o principal "civilizador de índios" da Bahia no período colonial foi, sem dúvida alguma, Domingos Álvares Branco Muniz Barreto. Nascido na Bahia por volta de 1748, Domingos Barreto fez parte de uma geração de intelectuais que ganhou espaço durante o reinado de d. Maria I (Novais, 2005; Silva, 1999). Barreto é autor do primeiro Plano sobre a civilização dos índios do Brasil de que se tem notícia, o qual foi escrito em 1788 e publicado postumamente em 1856 (Barreto, 1856).

A despeito de seu perfil de intelectual ilustrado, Barreto não deixou informações a respeito de sua formação. Seguiu carreira militar, ingressando na tropa regular em 1790, quando foi nomeado capitão de Infantaria do Regimento de Estremoz, que se encontrava destacado na praça do Rio de Janeiro. Desenvolveu diversos estudos em diferentes áreas de conhecimento, como mineralogia, botânica e economia, as quais redundaram em pequenos tratados ou memórias. A maioria não chegou a ser publicada. Teve atividade política destacada no Rio de Janeiro na primeira metade do século XIX, durante o processo de independência do Brasil em relação a Portugal. Faleceu em 1831, pouco depois de se reformar no elevado posto de marechal de campo ou tenente-general do Exército (Blake, 1970, v. II, p. 189-192; Delerue, 1998; Farias, 2010).

Sua atuação como "civilizador dos índios" concentrou-se em 1791 e 1792, quando visitou aldeias e vilas indígenas localizadas em Ilhéus e na Bahia. Embora a primeira versão do Plano sobre a civilização dos índios seja anterior às duas viagens, a experiência lhe valeu material para a redação de dois outros manuscritos, os quais não logrou publicar em vida. O primeiro reúne material da primeira viagem e consiste em uma memória de história natural que foi remetida à Academia de Ciências de Lisboa, com o título Viagem a parte da comarca dos Ilheos na capitania da Bahia. O segundo consiste na narrativa das duas viagens e tem por título Noticia da viagem, e jornadas que fez o capitaõ Domingos Alz Branco Muniz Barreto, entre os indios sublevados nas vilas e aldeas das comarcas dos Ilheos, e norte da capitania da Bahia. Barreto narrou também suas viagens em um requerimento no qual pediu à rainha a propriedade vitalícia do ofício de intendente da Marinha e Armazéns Reais da Bahia, pois pretendia se fixar na cidade de Salvador para cuidar dos negócios do pai, bastante idoso e doente. ${ }^{32}$

${ }^{32}$ O primeiro manuscrito encontra-se na Biblioteca da Academia de Ciências de Lisboa, Manuscrito 374 (Série azul), ff. 285-302. O segundo, na Biblioteca Nacional do Rio de Janeiro, Setor de Manuscritos, cota: 50, 1, O29. O requerimento pode ser encontrado em: AHU/BA, C.A., cx. 81, doc. 15.794. 
Não há nada de extraordinário no interesse de Barreto por cargos públicos, nem no artifício que utiliza para alcançá-los. A conquista de honras e mercês, normalmente traduzida na concessão de cargos e empregos, era uma motivação fundamental para a atividade intelectual no período colonial em uma sociedade marcada pelos rituais e estruturas do Antigo Regime (Raminelli, 2008). O intressante é que ele tenha enxergado a questão indígena como relevante tanto para as autoridades locais quanto para a Coroa, embora não tenha logrado, de imediato, aquilo que pretendia, sendo seu requerimento indeferido pelo Conselho Ultramarino e negado pela rainha. Sua ascensão na carreira militar, no entanto, pode ter sido impulsionada, em parte, por suas ações junto aos indígenas.

\section{A catequese empreendida pelos religiosos até o período pombalino diferia menos do que se possa imaginar do processo supostamente "civilizatório"}

A viagem de Barreto em direção à comarca de Ilhéus teve início no dia 2 de setembro de 1791. Ele afirma ter pacificado e conduzido de volta para suas aldeias e vilas vários índios que se achavam "descontentes e hum grande numero dispersos das suas habitaçoens, esquecidos muitos delles dos dogmas da religião, vivendo como brutos, á lei da natureza, differindo bem pouco dos barbaros gentios". Passou pelas aldeias de São Fidelis e Nossa Senhora dos Prazeres e pela vila de Santarém, que havia sido uma das aldeias administradas pelos jesuítas. Distribuiu diversos presentes, como "missangas, contas, veronicas, estampas, livros espirituaes, agulhas, linhas, dedaes, tesouras, brincos, pentes, navalhas, fitas, etc. e fazenda para vestiario e ferramentas para o trabalho da lavoura". Consciente da relação existente entre fidelidade religiosa e lealdade política, promoveu festividades públicas e mandou rezar missas em honra da família real, "para assim se radicarem os mesmos Indios, com os sagrados vinculos da Religiaõ no amor, e obediencia aos Soberanos" ${ }^{33}$

No ano seguinte, realizou sua segunda viagem, no distrito da comarca da Bahia da parte do norte, passando pela aldeia de Massarandupió e pela vila de Abrantes, antiga aldeia do Espírito Santo, administrada anteriormente pelos jesuítas. Em ambas construiu ou reformou casas e reuniu os índios que haviam se dispersado pela região. Distribuiu também por sua conta diversos presentes, além de arriscar a própria vida atravessando rios e matas. Por fim, fazendo jus a seu perfil de militar ilustrado, desenhou plantas das aldeias e vilas que visitou, tanto em Ilhéus quanto na Bahia, revelando aspectos significativos

${ }^{33}$ AHU/BA, C.A., CX. 81, doc. 15.794 
dessas povoações em relação à aplicação do Diretório dos Índios e à legislação pombalina como um todo. ${ }^{34}$

A respeito dos índios, fez coro à visão geral de que eram "gente inconstante, e sem firmeza" (Viveiros de Castro, 2002). Considerava-os, entretanto, aptos para o trabalho e capazes de desenvolver a lavoura mediante a fertilidade de suas terras. Em relação às povoações da capitania de Ilhéus, relatou que tanto os índios de Santarém quanto os da aldeia de São Fidelis eram robustos e bem inclinados para o trabalho, sendo bem empregados no corte de madeiras. Eram exímios navegadores e conhecedores de ervas e plantas. Os da vila de Santarém dedicavam-se às atividades tradicionais de caça e pesca, fazendo uso de seus antigos arcos "com destreza admirável". Os de São Fidelis fabricavam cordas, canoas e tecidos de algodão. Os da aldeia de Nossa Senhora dos Prazeres, ao contrário, eram "revoltozos e dados á embriaguez e assassinos". Seu comportamento poderia ser decorrência do descuido dos próprios portugueses, pois não tinham "á muito tempo ou para bem dizer á muitos annos Director que os advirta, nem parocho que os instrua". Ainda assim, alguns eram empregados no corte de madeiras e outros na agricultura. No tocante à comarca da Bahia, Barreto considerava os índios da aldeia de Massarandupió "muito doceis e de bons costumes", embora pouco instruídos. Os da vila de Abrantes eram "gente muito dada ao trabalho da lavoira". Produziam farinha em abundância e vendiam o excedente na cidade. Plantavam algodão e tinham uma olaria para fabricação de tijolos e telhas. ${ }^{35}$

Barreto não faz menção à atuação dos ouvidores junto às povoações indígenas, no entanto não poupa críticas aos diretores. Considerou o da vila de Santarém, por exemplo, "indigno deste exercício por sua ignorancia, como de commum são todos os que tem sido e são nomeados". A falta de bons diretores devia-se à baixa remuneração e ao fato de se terem unido (por comodidade) as funções de diretor e escrivão, como visto anteriormente. Na aldeia de Massarandupió sequer havia diretor, e o missionário responsável pela catequese cumpria também suas funções, "ainda que contra o disposto no Directorio dos Indios e reprovado por direito canonico, que impede semelhante jurisdicção aos mendicantes". Na vila de Abrantes, não obstante os índios se mostrassem mais adiantados do que os das outras povoações quanto às atividades produtivas e à forma de governo, não eram devidamente instruídos e educados, pois o diretor da vila era "não só ignorante, mas de pessimos costumes". Para ele, um verdadeiro diretor deveria ser "hum agente para educar e advertir aos Indios, protector e pae para os defender" ${ }^{36}$

Pode-se perceber nas críticas dirigidas por Domingos Barreto aos diretores e missionários das vilas e aldeias indígenas a predominância de uma situação

${ }^{34}$ AHU/BA, C.A., cX. 81, doc. 15.795-15.799; ABNRJ, XXXIV, p. 328-331. As plantas foram retiradas do requerimento e estão localizadas na Seção de Cartografia do Arquivo Histórico Ultramarino.

${ }^{35}$ AHU/BA, C.A., cX. 81, doc. 15.795-15.799; ABNRJ, XXXIV, p. 328-331. O algodão cultivado na vila de Abrantes aparece em um ofício do governador d. Fernando José de Portugal, datado de 11 de abril de 1796, referente à cultura de algodão na Bahia, sendo a espécie cultivada na vila (provavelmente pelos próprios índios) considerada "muito superior ao comum". AHU/BA, C.A., cx. 85, doc. 16.612.

${ }^{36}$ AHU/BA, C.A., cx. 81, doc. 15.798-15.799. 
ambígua, na qual, embora aparentemente não existisse uma preocupação efetiva com a aplicação do Diretório dos Índios e do alvará de 8 de maio de 1758, firmava-se um consenso em torno do ideal de civilidade e civilização dos índios e do papel a ser desempenhado pelas autoridades civis e militares nessa matéria. Nesse sentido, a despeito da ausência ou da má atuação dos diretores, o processo de civilização dos índios, instituído no contexto do reformismo ilustrado pombalino, tornava-se realidade, senão enquanto uma efetiva política de colonização, ao menos enquanto modelo a ser implantado.

\section{Considerações finais}

Apesar da negligência de diretores, escrivães e ouvidores e da permanência dos religiosos em algumas aldeias ou missões indígenas, os ideais de civilidade e civilização impuseram-se de modo crescente no discurso e na prática colonial luso-brasileira da segunda metade do século XVIII. Percebe-se na documentação que a palavra "civilização" se insere em um contexto de crítica e questionamento da obra catequética promovida no Brasil pelo clero regular, principalmente pelos jesuítas, acusados de não instruir os índios adequadamente na vida civil e no desempenho de funções úteis e produtivas à colônia.

Além dos ministros nomeados pelo tribunal do Conselho Ultramarino para a implantação da legislação pombalina e dos escrivães-diretores designados para as novas vilas indígenas, outras autoridades, como José Xavier Monteiro e Domingos Barreto, destacam-se nesse processo, tornando-se verdadeiros "agentes civilizadores de índios" na Bahia no último quartel do século XVIII. O primeiro, como ouvidor de uma comarca recém-criada que tinha nas populações indígenas um elemento-chave para o povoamento e o desenvolvimento da economia. O segundo, como militar e intelectual interessado na questão indígena em função de suas conexões com a produção do saber e a possibilidade de obter mercês e promoções. Ambos pautaram sua atuação pelo Diretório dos Índios, documento normativo e programático que lhes serviu de referência, mesmo não sendo inteiramente cumprido naquelas regiões da colônia. Suas ações revelam que o espaço deixado pelos religiosos foi sendo aos poucos ocupado por autoridades civis e militares imbuídas de ideais ilustrados e civilizadores, cumpridores de uma missão que pouco se preocupava com aquilo que realmente queriam os índios. 


\section{Referências bibliográficas}

ADAN, Caio Figueiredo Fernandes. Colonial comarca dos Ilhéus: soberania e territorialidade na América portuguesa (1763-1808). Dissertação (Mestrado em História), Universidade Federal da Bahia, Salvador, 2009.

ALMEIDA, Rita Heloísa. O Diretório dos Índios: um projeto de civilização no Brasil do século XVIII. Brasília: Universidade de Brasília, 1997.

BARRETO, Domingos Alves Branco Moniz. Plano sobre a civilisação dos índios do Brazil e principalmente para a capitania da Bahia, com uma breve noticia da missão que entre os mesmos índios foi feita pelos proscriptos jesuítas. Revista do Instituto Histórico e Geográfico Brasileiro, v. XIX, n. 21, p. 33-91, 1856.

BLAKE, Augusto Victorino Alves Sacramento. Diccionario bibliographico brazileiro. Brasil: Conselho Federal de Cultura, 1970.

BOER, Pim den. Civilização: comparando conceitos e identidades. In: FERES JR., João; JASMIN, Marcelo (Org.). História dos conceitos: diálogos transatlânticos. Rio de Janeiro: PUC-Rio/Loyola/Iuperj, 2007. BRUNET, Luciano Campos. De aldeados a súditos: viver, trabalhar e resistir em Nova Abrantes do Espírito Santo, Bahia 1758-1760. Dissertação (Mestrado em História), Universidade Federal da Bahia, Salvador, 2008.

CANCELA, Francisco Eduardo Torres. De projeto a processo colonial: índios, colonos e autoridades régias na colonização reformista da antiga capitania de Porto Seguro (1763-1808). Tese (Doutorado em História), Universidade Federal da Bahia, Salvador, 2012.

CHAMBOULEYRON, Rafael. Jesuítas e as crianças no Brasil quinhentista. In: DEL PRIORE, Mary (Org.). História das crianças no Brasil. 4. ed. São Paulo: Contexto, 2004.

DELERUE, Maria Luísa. Domingos A. B. Moniz Barreto: Baía, 1748, Rio de Janeiro 1831: entre o reformismo lusitano e a independência do Brasil. Dissertação (Mestrado em História Iberoamericana), Universidade Portucalense, Porto, 1998.

DOMINGUES, Ângela. Quando os índios eram vassalos: colonização e relações de poder no norte do Brasil na segunda metade do século XVIII. Lisboa: Comissão Nacional para as Comemorações dos Descobrimentos Portugueses, 2000.

ELIAS, Norbert. O processo civilizador. Rio de Janeiro: Jorge Zahar, 1994.

FALCON, Francisco Calazans. A época pombalina. 2. ed. São Paulo: Ática, 1993.

FARIAS, Poliana Cordeiro de. Domingos Alves Branco Muniz Barreto: ciência, economia e poder na Bahia (1788-1800). Dissertação (Mestrado em Ensino, Filosofia e História das Ciências), Universidade Federal da Bahia, Salvador; Universidade Estadual de Feira de Santana, Feira de Santana, 2010.

LEITE, Serafim. História da Companhia de Jesus no Brasil. Rio de Janeiro: Instituto Nacional do Livro, 1938-1950.

MARCIS, Teresinha. A integração dos índios como súditos do Rei de Portugal: uma análise do projeto, dos autores e da implementação na capitania de Ilhéus, 1758-1822. Tese (Doutorado em História), Universidade Federal da Bahia, Salvador, 2013.

MAXWELL, Kenneth. Marquês de Pombal: paradoxo do Iluminismo. Rio de Janeiro: Paz e Terra, 1996.

MONTEIRO, Nuno Gonçalo. D. José: na sombra de Pombal. Lisboa: Círculo de Leitores, 2006. NOVAIS, Fernando. Portugal e o Brasil na crise do antigo sistema colonial (1777-1808). 8. ed. São Paulo: Hucitec, 2005.

RAMINELLI, Ronald. Viagens ultramarinas: monarcas, vassalos e governo a distância. São Paulo: Alameda, 2008.

SANTOS, Fabricio Lyrio. Da catequese à civilização: colonização e povos indígenas na Bahia (1750-1800). Tese (Doutorado em História), Universidade Federal da Bahia, Salvador, 2012.

. "Te Deum laudamus": a expulsão dos jesuítas da Bahia (1758-1763). Dissertação (Mestrado em História), Universidade Federal da Bahia, Salvador, 2002.

SILVA, Maria Betriz Nizza da. A cultura luso-brasileira: da reforma da universidade à independência do Brasil. Lisboa: Editorial Estampa, 1999.

VILHENA, Luís dos Santos. A Bahia no século XVIII. Salvador: Itapuã, 1969.

VIVEIROS DE CASTRO, Eduardo. O mármore e a murta: sobre a inconstância da alma selvagem. In: _. A inconstância da alma selvagem e outros ensaios de antropologia. São Paulo: Cosac Naify, 2002. 